\title{
The Role of Creative Self-Efficacy to Increase Researcher's Innovative Behavior
}

\author{
Metha Djuwita Supriatna
}

To Link this Article: http://dx.doi.org/10.6007/IJARBSS/v9-i9/6376

DOI: $10.6007 /$ IJARBSS/v9-i9/6376

Received: 11 July 2019, Revised: 20 August 2019, Accepted: 30 August 2019

Published Online: 21 September 2019

In-Text Citation: (Supriatna, 2019)

To Cite this Article: Supriatna, M. D. (2019). The Role of Creative Self-Efficacy to Increase Researcher's Innovative Behavior. International Journal of Academic Research in Business and Social Sciences, 9(9), 846859.

\section{Copyright: (c) 2019 The Author(s)}

Published by Human Resource Management Academic Research Society (www.hrmars.com)

This article is published under the Creative Commons Attribution (CC BY 4.0) license. Anyone may reproduce, distribute, translate and create derivative works of this article (for both commercial and non-commercial purposes), subject to full attribution to the original publication and authors. The full terms of this license may be seen at: http://creativecommons.org/licences/by/4.0/legalcode

\section{Vol. 9, No. 9, 2019, Pg. 846 - 859}

Full Terms \& Conditions of access and use can be found at http://hrmars.com/index.php/pages/detail/publication-ethics 


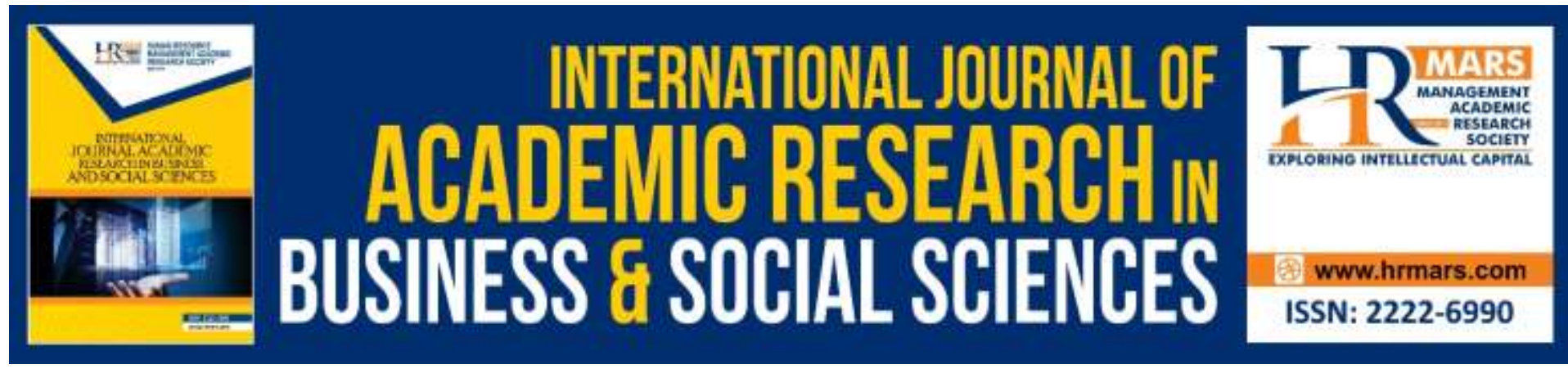

\title{
The Role of Creative Self-Efficacy to Increase Researcher's Innovative Behavior
}

\author{
Metha Djuwita Supriatna \\ School of Administration, National Agency for State Administration, Bandung, West Java, \\ Indonesia
}

\begin{abstract}
The purpose of this study is to determine the role of creative self-efficacy in increasing the innovative behavior of the researchers at the Centre for Water Resources Research and Development, Ministry of Public Works and Public Housing. This study implemented a quantitative paradigm with the verification method. The questionnaire was spread for data collection. The respondents were 48 civil servants with the functional position as a researcher. The results of this research showed that creative self-efficacy has strong relationship with innovative behavior of the researchers. As expected, the results of simple regression analysis in this study reveal the significant impact of creative self-efficacy on innovative behavior in public sector organization. Therefore, this investigation contributes to the existing body of knowledge by providing a specific explanation on creative self-efficacy and innovative behavior in public organization.
\end{abstract}

Keywords: Creative Self-Efficacy, Innovative Behavior, Researcher, Public Sector Organization.

\section{Introduction}

The development of the infrastructure is one of the national priorities in Indonesia, as mentioned in NawaCita, the manuscript of development vision by President of Republic Indonesia. To achieve the targets, various Ministries, Institutions, and other organizations should be well-coordinated. One of the ministries involved in infrastructure development is the Ministry of Public Works and Public Housing. The Center for Water Resources Research and Development (Puslitbang SDA) is one of four research and development institutions, under the Research and Development Agency, Ministry of Public Works and Public Housing. The vision of Puslitbang SDA is to become a leader in producing technology and providing expert services to support the availability of reliable water resource infrastructure. The main tasks that must be carried out by this organization include conducting research, development, and application of science and technology in the field of water resources. Based on the organizational vision and main tasks instructed by the Research Center for Natural Resources, the functional position of researchers considered having a strategic position in achieving the vision and fulfillment of the main tasks of the Research Center for Natural Resources. 
In knowledge-based societies where competition is highly intense, innovation is determined as a critical factor for the success of organizations. From the NPM (New Public Management) doctrines, problems arose from "government failures" regarding the inability of hierarchical, centralized, and organized systems to adapt to the fast-changing environment (Walsh, 1995). In order to establish alternative forms of service delivery and better policy implementation, NPM is considered as an alternative way to create more innovative and, hence, better performing public organizations (Dunleavy, 1997).

Recently, Wynen et al., (2019) stated while a psychological literature rise on organizational responses to change might hamper organizational innovation especially for rapid change, the processes of change in the public sector and its relationship with subsequent innovative behaviors is still puzzling. Previous scholars in their study use the conservation of conventional theory to investigate the effects of organizational innovation climate and its interactions with employee innovative behavior (Bos-nehles \& Veenendaal, 2017; Hsu \& Chen, 2015).

Innovation in such organizations depends on people's behavior. Individuals' innovative behavior has been considered as an important human capital that contributes to a firm's competitive advantage. Therefore, innovative behavior among officers in public organization is crucial for organizational success, in which this could be seen as a process in generating, creating, developing, applying, promoting, realizing, and modifying new ideas in order to benefit role performance.

The definition of innovative behavior is a gradual process in which individuals generate new ideas or solutions for problems that have been identified. The ideas of the solution then emphasized to create an innovative model that is useful for organizations (Carmeli et al., 2006; Shih \& Susanto, 2011). The individual who implements the innovative behavior will show some characters, such as: (1) seek out new technologies, processes, techniques, and new ideas, (2) generate creative ideas, (3) promote ideas to others, (4) research and provide resources to realize new ideas, and (5) develop plans and timelines to realize these new ideas(George \& Zhou, 2001).

Individual innovation forms in the workplace are seen as complex behaviors consisting of three stages (Scott \& Bruce, 1994). In the first stage, individuals will recognize a problem and produce a new solution. In the second stage, individuals will look for ways to promote ideas and solutions offered to build legitimacy and support from both inside and outside the organization. In the final stage, an individual will show innovative behavior by producing an innovation model or prototype that can be used and applied by organizations. Innovative behavior is considered as a manifestation of the real contribution of human resources to create an organization's competitive advantage.

Innovative human resources (HR) is an important asset that enables organizations to succeed in a dynamic environment (Kor \& Mahoney, 2000; Yuan \& Woodman, 2010). In particular, innovative behavior in the workplace of an employee is considered an important prerequisite for the survival of the organization(Hon \& Lui, 2016). Innovative behavior refers to individual actions that lead to the introduction and application of new things and benefit the organization. Someone who has innovative behavior will always think critically and strive for a change that has a certain use or added value (Sujarwo, 2017). Study of Hsu et al., (2011) have revealed that someone with high innovative behavior tends to have high creative selfefficacy. 
The concept of creative self-efficacy is rooted in Bandura's social cognitive theory (Bandura, 1986), self-efficacy is an important determinant of behavior and specific goaloriented through motivation, cognitive, and affective process interventions. Briefly, selfefficacy is the things that a person believes to be achieved by using skills in a particular environment (Park \& Lew, 2017). Self-efficacy has conceptually linked to motivation and perseverance, or willingness to continue activity in the face of setbacks. Self-efficacy not only affect individual choice in matters of career, but also of the effort, mindset, and emotional reactions when faced with obstacles (Goodwin, 2019). Thus, a person with high self-efficacy has a capability to control him/herself to cope up with any situation occurred (Chen, 2016).

Creative self-efficacy is the application of the concept of self-efficacy to a particular field of creativity and is considered a key personal attribute in creativity at work (Shiu \& Lin, 2012). Creative self-efficacy refers to an individual self-belief in which they can produce creative outcomes or to perform certain tasks in the innovation process (Hsu et al., 2011; Tan, Li, \& Rotgans, 2011; Tierney \& Farmer, 2011). Factors that determine the self-efficacy framework are (1) knowledge gained through experience, (2) knowledge gained through observation, (3) verbal encouragement from third parties, and (4) emotional activation.

\section{Research Purpose and Problems}

This study was motivated by a gap in the literature on understanding how innovative behavior was enforced by creative self-efficacy. As Bos-nehles \& Veenendaal (2017) mentioned that organizations could be fostering desired behaviors by applying HR practices in which encourage specific and objective attitudes and behaviors, and this could also discourage undesired behaviors. Most of previous studies only focus on innovation at the organizational level such as organizational innovation climate (Bos-nehles \& Veenendaal, 2017; Hsu \& Chen, 2015), where HR practices or HR systems have been shown to affect innovative outcomes (Seeck \& Diehl, 2017).

While lack of innovation is recognized as a perceived problem to public organization, particularly innovative behavior considered as a practice of spontaneous adaptation (Verhoest, Verschuere, \& Bouckaert, 2007). This would lead to the rise of the risk faced by many employees in the innovation process. Consequently, it would be interesting to examine innovation process at the individual level process. Based on social cognitive theory, general self-efficacy is conceptually explained as a positive belief about personal control over success. Social cognitive theory indicates that people are motivated by their belief about their own capabilities in order to perform specific tasks (or behaviors) and by their expectations about how good outcomes of their actions (Bandura, 1986). General self-efficacy positively correlated and show positive effects on various desirable outcomes (Judge \& Bono, 2001; Judge et al., 2003). As derivation from that concept, creative self-efficacy reflects one's confidence in the ability to perform a specific task in the innovation process (Hsu et al., 2011). The research questions remain: how to enhance an innovative behavior for public organization from the researchers' creative self-efficacy? How well the efficacy and innovative behavior are perceived by researchers in public organization?

Self-efficacy has an important role in encouraging the optimization of the potential possessed (Rustika, 2012). Self-efficacy relates to an individual's belief in their ability to complete tasks and indirectly influences the definition of goals and actions to be achieved (Damperat et al., 2016). In addition, creative self-efficacy can affect individual motivation (Shiu \& Lin, 2012). Given the underlined of social cognitive in shaping innovative attitude and 
behavior, this study intends to recognize the effects of the self-efficacy on individuals innovative behavior in Puslitbang SDA. As a public organization, Puslitbang SDA considered as a systematic organization, and during its development, the process of organizational innovation is critical, as it would fostering organizational performance. Regarding to the problems and gap mentioned above, the purposes of this study are as follows:

1. To measure the value of creative self-efficacy and innovative behavior among researchers in public organization.

2. To validate the internal consistency of the construct of creative self-efficacy and innovative behavior.

3. To examine the effect of researchers' creative self-efficacy on innovative behavior.

\section{Method}

The cross-sectional design in this study used a quantitative paradigm. The information collected in this study consist of two variables, creative self-efficacy and innovative behavior. This research used descriptive and verification methods. Verification method was carried out to analyze the effect of creative self-efficacy on innovative behavior in the functional position of the researcher. This verification method is carried out by using a survey method.

This study takes place in public organizations. Respondents in this study are researchers who work at Puslitbang SDA. The researcher is a position that has the scope of duties, responsibilities, and authorities to carry out research, development, and study of science and technology in research, development, and assessment of government agencies. The position of the functional researcher is regulated in the regulation of the Ministry of Administrative and Bureaucratic Reform of the Republic Indonesia number 34 of 2018. According to this regulation, researchers have a responsibility as a technical practitioner in conducting research, development, and assessment activities related to science and technology. The levels of the researcher positions from the lowest to the highest level are First Expert Researcher, Young Expert Researcher, Associate Expert Researcher, and Main Expert Researcher. One of the researcher tasks is to publish the results of research/development activities in the form of books, anthologies, and scientific articles, to produce novelty in intellectual property. At the headquarters of Puslitbang SDA, there are 94 researchers out of a total of 321 employees. Researchers are expected to actively innovate in producing research or development of published works either in the form of scientific articles or intellectual property.

The research sample was chosen by purposive sampling. The population of researchers was ninety-four people. Determination of the sample was done by the saturated sample method by taking the whole of the population that has been identified. A total of 48 researchers became respondents in this study. As a result, the response rate for this study was 51.06 percent.

The instrument which implemented in this study was a questionnaire adapted and developed from several theoretical experts in previous empirical research. Creative selfefficacy was adapted from instruments developed by Brockhus et al.,(2014), which consists of fifteen (15) indicator indicators. Meanwhile, to measure innovative behavior, the construct was adapted from the instrument developed by Yu et al., (2013), which consists of nine (9) statement indicators. The items adapted from this study were measured using a Likert scale consisting of five ratings, as seen in Table 1. 
Quantitative method used in this study by applying descriptive analysis and linear regression analysis to analyze data in this study. Linear regression analysis was applied to analyze the effect of creative self-efficacy on innovative behavior. Descriptive analysis was used to provide an overview related to the research variables. The categorization of the respondents' response criteria follows the Durianto (2013).

Table 1. Criteria for Respondents Response

\begin{tabular}{ccc}
\hline & $\begin{array}{c}\text { Creative Self- } \\
\text { Efficacy }\end{array}$ & $\begin{array}{c}\text { Innovative } \\
\text { Behavior }\end{array}$ \\
\hline $1-1.7$ & Very Low & Very Low \\
$1.8-2.5$ & Low & Low \\
$2.6-3.3$ & Medium & Medium \\
$3.4-4.1$ & High & High \\
$4.2-5$ & Very High & Very High \\
\hline
\end{tabular}

\section{Results}

The validity and reliability of the questionnaire examined before the research data is analyzed. The results of the validity test of the variables of creative self-efficacy and innovative behavior can be seen in the table below.

Table 2. The Validity of Creative Self-Efficacy \& Innovative Behavior

\begin{tabular}{cccccccc}
\hline \multicolumn{6}{c}{ Creative Self-Efficacy } & \multicolumn{5}{c}{ Innovative Behavior } \\
Item & r count & r critical & Information & Item & r count & r critical & Information \\
\hline 1 & 0.558 & 0.30 & Valid & 1 & 0.857 & 0.30 & Valid \\
2 & 0.474 & 0.30 & Valid & 2 & 0.856 & 0.30 & Valid \\
3 & 0.569 & 0.30 & Valid & 3 & 0.838 & 0.30 & Valid \\
4 & 0.634 & 0.30 & Valid & 4 & 0.593 & 0.30 & Valid \\
5 & 0.837 & 0.30 & Valid & 5 & 0.471 & 0.30 & Valid \\
6 & 0.910 & 0.30 & Valid & 6 & 0.475 & 0.30 & Valid \\
7 & 0.578 & 0.30 & Valid & 7 & 0.749 & 0.30 & Valid \\
8 & 0.852 & 0.30 & Valid & 8 & 0.823 & 0.30 & Valid \\
9 & 0.717 & 0.30 & Valid & 9 & 0.884 & 0.30 & Valid \\
10 & 0.776 & 0.30 & Valid & & & & \\
11 & 0.896 & 0.30 & Valid & & & & \\
12 & 0.793 & 0.30 & Valid & & & & \\
13 & 0.748 & 0.30 & Valid & & & & \\
14 & 0.590 & 0.30 & Valid & & & & \\
15 & 0.611 & 0.30 & Valid & & & & \\
\hline
\end{tabular}

Table 2 shows that the creative self-efficacy variable could represent the object of the study. Based on the results of testing the validity of all creative self-efficacy variable statement items, the value of the correlation coefficient $>0.3$. It means that all items are valid statements ( $r$ count $>r$ critical). Validity test conducted on innovative behavior variable 
statement items shows that all are valid (>0.3).So it can be concluded that the innovative behavior variables in the questionnaire have represented the object under study.

Table 3. Reliability Test Results

\begin{tabular}{lccc}
\hline & $\begin{array}{c}\text { Cronbach's } \\
\text { Alpha }\end{array}$ & N of items \\
\hline $\begin{array}{l}\text { Creative } \\
\begin{array}{l}\text { Efficacy } \\
\text { Innovative Behavior }\end{array}\end{array}$ & .926 & 15 \\
\hline
\end{tabular}

Reliability test of the questionnaire carried out using Cronbach's Alpha technique to determine the consistency of the measure. Reliability test results can be seen in the value of the reliability coefficient in Table 3 . The reliability value for the creative self-efficacy variable was 0.926 , and 0.896 for the innovative behavior variable. It means that all statements on the questionnaire can be said to be reliable (Cronbach's alpha value>0.6). So it can be concluded that all instruments used in the creative self-efficacy variable questionnaire and innovative behavior are valid and reliable.

Table 4. Characteristics of Respondents (Gender)

\begin{tabular}{ccc}
\hline Gender & Total & Percentage \\
\hline Male & 34 & 70.83 \\
Female & 14 & 29.17 \\
\hline
\end{tabular}

Table 5. Characteristics of Respondents (Education)

\begin{tabular}{ccc}
\hline Education & Total & Percentage \\
\hline Bachelor & 6 & 12.50 \\
Master Degree & 40 & 83.33 \\
Doctoral & 2 & 4.17 \\
\hline
\end{tabular}

Characteristics of respondents involved in this study were categorized into several criteria, including gender and education. As seen in Table 4, the majority nearly three-quarters of the respondents, of the researchers were male due to the core business of Puslitbang SDA is engineering. Based on the respondents' education background, almost half of the respondents already have a master's education.Indicated that the majority of researchers in Puslitbang SDA already have high-quality competency standards, so it is assumed that the respondents are able to handle and analyze problems in their fields. On the other hand, there are still individuals with Bachelor Degree as a researcher in Puslitbang SDA. Based on the policy of the first appointment in the functional position of the researcher, one of the criteria that must be met is to have a Masters education. Based on PermenPAN-RB Number 34 of 2018, researchers who do not yet have a master degree must acquire that within five years after the enactment of the Ministerial Regulation.

The mean value of each statement item on the creative self-efficacy variable and the innovative behavior variable is used as the basis for the interpretation of respondents' responses. The mean score of statement items on both research variables can be seen in table 6. 
Table 6. Average Statement Item Score

\begin{tabular}{cccccc}
\hline \multicolumn{5}{c}{ Creative Self-Efficacy } & \multicolumn{3}{c}{ Innovative Behavior } \\
Item & Mean & Category & Item & Mean & Category \\
\hline 1 & 4.13 & High & 1 & 3.63 & High \\
2 & 3.92 & High & 2 & 3.60 & High \\
3 & 3.83 & High & 3 & 3.83 & High \\
4 & 3.88 & High & 4 & 4.10 & High \\
5 & 3.67 & High & 5 & 3.58 & High \\
6 & 3.62 & High & 6 & 3.73 & High \\
7 & 3.69 & High & 7 & 3.65 & High \\
8 & 3.65 & High & 8 & 3.65 & High \\
9 & 3.31 & Medium & 9 & 3.77 & High \\
10 & 3.67 & High & & & \\
11 & 3.58 & High & & & \\
12 & 3.35 & Medium & & & \\
13 & 3.69 & High & & & \\
14 & 3.81 & High & & & \\
15 & 3.79 & High & & & \\
\hline
\end{tabular}

Based on the average calculation of the total score of creative self-efficacy variables and innovative behavior, it can be seen that the mean value for creative self-efficacy is 3.71 and innovative behavior is 3.73

Table 7. Average Total Variable Score

\begin{tabular}{ccc}
\hline Variable & Mean & Category \\
\hline Creative Self-Efficacy & 3.71 & High \\
Innovative Behavior & 3.73 & High \\
\hline
\end{tabular}

Simple linear regression statistical tests are used in analyzing the effect of creative selfefficacy variables $\left(X_{1}\right)$ on innovative behavior variables $\left(X_{2}\right)$. The value of the constant $(a)$ is 9,189 , which means the value of the positive constant. It shows that if the creative selfefficacy $\left(X_{1}\right)$ is zero, then the growth of innovative behavior $\left(X_{2}\right)$ is 9,189 . The regression coefficient for the creative self-efficacy variable $\left(X_{1}\right)$ is 0.438 , which means it has a positive value. This shows a direct relationship between creative self-efficacy and innovative behavior.

Table 8. Calculation Result of Simple Linear Regression Analysis The Effect of Creative Self Efficacy $\left(X_{1}\right)$ on Innovative Behavior $\left(X_{2}\right)$

\begin{tabular}{|c|c|c|c|c|c|}
\hline & \multicolumn{3}{|c|}{ Unstandardized Coefficients } & \multirow[t]{2}{*}{$\mathrm{t}$} & \multirow[t]{2}{*}{ Sig. } \\
\hline & B & Std. Error & Beta & & \\
\hline (Constant) & 9.189 & 2.830 & & 3.248 & .002 \\
\hline $\begin{array}{l}\text { Creative Self- } \\
\text { Efficacy (X1) }\end{array}$ & .438 & .050 & .788 & 8.686 & .000 \\
\hline
\end{tabular}

The results of the analysis of the coefficient of determination in this study indicate that the value of $\mathrm{R}$ Square is 0.621 . That is, $62.1 \%$ of innovative behavior can be explained by creative self-efficacy, and the remaining $37.9 \%$ can be explained by other variables. 
Table 9. Determination Coefficient Value

\begin{tabular}{ccc}
\hline Model & $\mathrm{R}$ & $\mathrm{R}$ Square \\
\hline 1 & .788 & .621 \\
\hline
\end{tabular}

\section{Discussion}

Based on table 6, creative self-efficacy variable is almost all statement items included in the high category. From these results, it can be concluded that researchers at the Puslitbang SDA assessed themselves as innovative, creative, have a positive self-image, and believe in their creative abilities. It shows that the researchers at the Puslitbang SDA will be able to find the solution to the problem by developing creative ideas. The results also shows that they are capable of expressing their ideas to others. The result also shows that they are capable of expressing their ideas to others. The results are supported by research conducted by Park (2016), where individuals who have high self-efficacy will have the ability to solve problems better.

In the creative self-efficacy variable, there are still two items of statements that are included in the moderate category, namely when researchers compare their ideas with other researchers' ideas and confidence in producing a solution that is different from the others. That is, although researchers at the Puslitbang SDA assess themselves creative and innovative, there is still a feeling that the ideas/solutions produced are equivalent to the ideas/solutions produced by other researchers.

The results of the average score of innovative behavior variable statement items indicate that all statement items in the high category. Researchers at the Puslitbang SDA consider themselves able to create new ideas, find work methods or new techniques, be able to produce solutions to problems, and apply innovative ideas into useful things. Researchers at the Puslitbang SDA support each other's innovative ideas and feel they have received approval or support from the work environment for their innovative ideas. The enthusiasm of researchers for innovative ideas generated in the work environment makes researchers themselves want to introduce innovative ideas and evaluate the usefulness of innovative ideas.

Based on the average calculation of the two research variables, creative self-efficacy and innovative behavior of the researcher are categorized in the high category. It says that the researchers at thePuslitbang SDA have confidence that they can produce creative outcomes and perform certain tasks in the innovation process. Besides, researchers at the Puslitbang SDA can generate new ideas or solutions to the problems that have been identified, then promote their solutions to build support for them, and ultimately create useful innovation models.

Although the average of the total score of creative self-efficacy and innovative behavior is in the high category, it still possible to be improved through series of training or selfdevelopment activities that focus on increasing employee's motivation. One important point of creative self-efficacy is motivation. By maintaining employee's motivation will results in the more diligent employees and better at dealing with problems so that they have a higher value of creative self-efficacy. The other way of the improvement is by giving examples and support from super-ordinated. As a superior, it will be more positive if he/she is not always asking innovation from his/her subordinates, but shows his/her innovative idea as well. It is 
necessary to give examples from superiors who actively produce a research/innovation output. Support from superiors is considered important, by providing the necessary facilities and infrastructures, will make researchers more enthusiastic in generating creative ideas. Another way of improvement is in terms of management in shaping an environment that supports innovation. For example, arranging a regular meeting for researchers to discuss the actual issues and challenges. With these regular meetings, it is expected to transmit creative self-efficacy and innovative behavior among researchers at the Research and Development Center for Natural Resources.

Simple linear regression statistical test results show that if every increase in creative selfefficacy will increase innovative behavior. Meanwhile, if there is a decrease in creative selfefficacy will reduce innovative behavior. Correlation coefficient analysis is used to determine the direction and strength of the relationship between the two variables. Correlation coefficient test results show that between creative self-efficacy variables with innovative behavior has a regression value (coefficient of influence) of 0.788 . Therefore it can be concluded that the correlation coefficient between the two variables is at the level of a strong relationship.

The results of the analysis of the coefficient of determination show that $62.1 \%$ of innovative behavior can be explained by creative self-efficacy, and the remaining $37.9 \%$ can be explained by other variables. Other variables that can explain innovative behavior include transformational leadership styles and self-leadership (Lee et al., 2007); and organizational commitment (Jafri, 2010). But this research reveals the large explanatory variants of creative self-efficacy on innovative behavior.

The amount of contribution of creative self-efficacy in explaining innovative behavior can occur because the perception of creative self-efficacy possessed by individuals can affect the way of thinking, motivation, behavior, and emotional level of a person. So individuals with high creative self-efficacy, when faced with an obstacle, or negative comments from others, will tend not to give up easily and are more positive in dealing with it. Individuals with high self-efficacy will also continue to think critically in finding innovative ideas/solutions. Some social obstacles can prevent individuals from innovating. It is important for management level to build a system of social support and recognition that can encourage one's innovative behavior.

Test the significance of the influence between variables using the t-test to test the hypothesis of whether creative self-efficacy influences innovative behavior. The hypotheses tested are (1) $\mathrm{H}_{0}: \beta_{1}=0$ "Variables of creative self-efficacy $\left(X_{1}\right)$ do not influence innovative behavior $\left(X_{2}\right)$ "; $(2) H_{1}: \beta_{1} \neq 0$ "Variable creative self-efficacy $\left(X_{1}\right)$ influences innovative behavior $\left(\mathrm{X}_{2}\right)$ ". The significant level used in this study was $5 \%(0.05)$ with a degree of freedom $\mathrm{df}=\mathrm{n}$ $k=48-2=46$. Then the $t$-table value of 1.6787 was obtained. The t-test statistic value for creative self-efficacy is 8,686 , and the sig ( $p$-value) of creative self-efficacy is 0,000 . With the test, criteria are starting $\mathrm{H}_{0}$ if the $\mathrm{t}$-count $\geq$ table or Sig value $(\mathrm{p}$-value) $\leq 0.05$. Based on the testing criteria, the $t$-value of the creative self-efficacy variable $=8,686>t$-table $=1.6787$ and the value of Sig ( $p$-value) of creative self-efficacy $<0.05$ which is 0.000 then $\mathrm{H}_{0}$ is rejected. That is, with a $95 \%$ confidence level, it is reasonable to suggest a regression coefficient of creative self-efficacy means in the model, or it can be concluded that the creative self-efficacy variable has an influence on innovative behavior, or creative self-efficacy has a role in increasing innovative behavior for the researcher functional position. This research has important implications for public sector organizations, where it can be seen thatCreative self-efficacy 
has a role in enhancing innovative behavior. Creative self-efficacy can be developed through training, as well as self-development. Therefore, organizations need to support the functional positions of researchers to innovate by recognizing an important role in innovative tasks. Organizations need to build a positive work environment that can encourage the improvement of innovative behavior of researchers in functional positions, one of which is by using team-based collaboration. These things will make employees with functional positions, as researchers become more confident and confident and tend to be more creative because of the support of the organization to take risks and face failure in innovation.

\section{Conclusion}

In sum, there is high rate of moderately high level of creative self-efficacy and innovative behavior among researchers in Center for Research and Development of Water Resources, the Ministry of Public Works and Public Housing (Puslitbang SDA). The present study also confirmed that internal consistency is acceptable for both creative self-efficacy and innovative behavior among researchers in Puslibang SDA. We extend this line of research on innovative behavior by demonstrating meaningful findings that show the important and high effect of creative self-efficacy on innovative behavior.

Employees with functional positions of researchers should actively innovate to produce ideas which are then published both in the form of scientific work, books, and Intellectual Property. Especially for the functional position of researchers in Puslitbang SDA which is considered to have a strategic position in supporting the achievement of the organization's vision and fulfillment of basic tasks.

In this study, it was found that researchers at Puslitbang SDA had creative self-efficacy included in the high category. It means that as a researcher, they have confidence that they are capable of producing creative outcomes and carrying out certain tasks in the innovation process. Innovative behavior possessed by researchers is also included in the high category. That is, researchers at the SDA Research Center can generate ideas or new solutions to the problems that have been identified, then promote the solutions they have to build support for them, and ultimately create a useful innovation model. Although creative self-efficacy and innovative behavior are in the high category, they can still be improved by (1) training and self-development, (2) giving examples and support from superiors, and (3) forming an environment that supports innovation.

Also, it can be seen that creative self-efficacy plays an important role in enhancing innovative behavior for employees with the researcher positions. That is, an increase in researchers' innovative behavior can be explained by creative self-efficacy. The amount of contribution of creative self-efficacy in explaining innovative behavior can occur because the perception of creative self-efficacy possessed by individuals can affect the way of thinking, motivation, behavior, and emotional level of a person. So individuals with high creative selfefficacy, when faced with an obstacle, or negative comments from others, will tend not to give up easily and are more positive in dealing with it.

\section{Limitation and Future Research}

This study had several limitations, and therefore, this paper offers suggestions for future research. This research is inseparable from some limitations that arise, among others, first that the generalization of research results only applies to Puslitbang SDA. Both of the characteristics of self-assessment by respondents have the potential to bring up bias in the 
assessment of self-perception regardless of the value of the validity and reliability of data that has been found to meet their respective criteria, namely valid and reliable. Future research is suggested to be able to review other factors that are considered to have a relationship between creative self-efficacy and innovative behavior. As innovative behavior is vital to organizational competitiveness in a dynamic environment, it is crucial to identify what other factors could foster innovativeness. Besides, this research model is recommended to be developed and tested on other objects with more general characteristics to enable the broader generalization of results.

\section{References}

Bandura, A. (1986). From Thought to Action: Mechanisms of Personal Agency. New Zealand Journal of Psychology, 15(1), 1-17.

Bos-nehles, A. C., \& Veenendaal, A. A. R. (2017). Perceptions of HR practices and innovative work behavior : the moderating effect of an innovative climate. The International Journal of Human Resource Management, (September), 1-23.

https://doi.org/10.1080/09585192.2017.1380680

Brockhus, S., Kolk, T. E. C. van der, Koeman, B., \& Badke-Schaub, P. G. (2014). The Influence of creative Self-Efficacy on Creative Performance. Proceeding of International Design Conference DESIGN 2014, 437-444.

Carmeli, A., Meitar, R., \& Weisberg, J. (2006). Self-Leadership Skills and Innovative Behavior at Work. International Journal of Manpower, 27(1), 75-90.

https://doi.org/10.1108/01437720610652853

Chen, I.-S. (2016). Examining the Linkage Between Creative Self-Efficacy and Work Engagement. Baltic Journal of Management, 11(4), 516-534.

https://doi.org/10.1108/bjm-04-2015-0107

Damperat, M., Jeannot, F., Jongmans, E., \& Jolibert, A. (2016). Team Creativity: Creative SelfEfficacy, Creative Collective Efficacy and Their Determinants. Recherche et Applications En Marketing, 31(3), 6-25. https://doi.org/10.1177/2051570716650164

Dunleavy, P. (1997). The Globalization of Public Services Production: Can Government Be 'Best In theWorld? In A. Massey (Ed.), Globalization and Marketization of Government Services. Basingstoke, UK: Macmillan.

Durianto, D., Sugiarto, W., Widjaja, W., \& Supraktino, H. (2013). Invasi Pasar dengan Iklan yang Efektif: Strategi, Program, dan Teknik Pengukuran. Jakarta: Gramedia Pustaka Utama.

George, J. M., \& Zhou, J. (2001). When Openness to Experience and Conscientiousness are Related to Creative Behavior: an Interactional Approach. Journal of Applied Psychology, 86(3), 513-524. https://doi.org/10.1037/0021-9010.86.3.513

Goodwin, K. (2019). Developing Self-Efficacy and Career Optimism Through Participation in Communities of Practice Within Australian Creative Industries. Australian Journal of Career Development, 28(2), 122-131. https://doi.org/10.1177/1038416219849644

Hon, A. H. Y., \& Lui, S. S. (2016). Employee Creativity and Innovation in Organizations: Review, Integration, and Future Directions for Hospitality Research. International Journal of Contemporary Hospitality Management, 28(5), 862-885.

https://doi.org/10.1108/IJCHM-09-2014-0454 
Hsu, M. L. A., \& Chen, F. H. (2015). The Cross-Level Mediating Effect of Psychological Capital on the Organizational Innovation Climate - Employee Innovative Behavior Relationship. The Journal of Creative Behavior, 51(2), 1-16. https://doi.org/10.1002/jocb.90

Hsu, M. L. A., Hou, S., \& Fan, H. (2011). Creative Self-Efficacy and Innovative Behavior in a Service Setting : Optimism as a Moderator. Journal of Creative Behavior, 45(4), 258-272.

Jafri, M. H. (2010). Organizational Commitment and Employee's Innovative Behavior. Journal of Management Research, 10(1), 62-68.

https://doi.org/10.1016/j.annepidem.2014.11.011

Judge, T. A., \& Bono, J. E. (2001). Relationship of core self-evaluations traits - self-esteem, generalized self-efficacy, locus of control, and emotional stability - with job satisfaction and job performance: A meta-analysis. Journal of Applied Psychology, 86, 80-92. https://doi.org/10.1037/0021-9010.86.1.80

Judge, T. A., Erez, A., Bono, J. E., \& Thoresen, C. J. (2003). The core self-evaluations scale: Development of a measure. Personnel Psychology, 56, 303-331. https://doi.org/10.1111/j.1744-6570.2003.tb00152.x

Kor, Y. Y., \& Mahoney, J. T. (2000). Penrose's Resource-Based Approach: The Process and Product of Research Creativity. Journal of Management Studies, 37(110-139). https://doi.org/10.1111/1467-6486.00174

Lee, C. S., Lee, W., \& Kim, J. (2007). Effects of Transformational Leadership and Self-leadership on Innovative Behaviors: Mediating Roles of Empowerment. International Area Studies Review, 10(2), 163-176. https://doi.org/10.1177/223386590701000210

Park, S. H. (2016). Exploration on Relation between Creative Self-Efficacy and Disposition of Problem-Solving. Information, 19(8), 3383-3388.

Park, S. H., \& Lew, K. H. (2017). A Study on Pre-Service and In-Service Teachers' Creative SelfEfficacy and Creative Self-Assessment. International Information Institute, 20(7), 52815288.

Rustika, I. M. (2012). Efikasi Diri: Tinjauan Teori Albert Bandura. Buletin Psikologi, 20(1-2), 18-25. https://doi.org/10.22146/bpsi.11945

Scott, S. G., \& Bruce, R. A. (1994). Determinants of Innovative Behavior: A Path Model of Individual Innovation in the Workplace. Academy of Management Journal, 37(3), 580607. https://doi.org/10.5465/256701

Seeck, H., \& Diehl, M. R. (2017). A literature review on HRM and innovation-taking stock and future directions. The International Journal of Human Resource Management, 28(6), 913-944.

Shih, H. A., \& Susanto, E. (2011). Is Innovative Behavior Really Good for The Firm?: Innovative Work Behavior, Conflict with Coworkers and Turnover Intention: Moderating Roles of Perceived Distributive Fairness. International Journal of Conflict Management, 22(2), 111-130. https://doi.org/10.1108/10444061111126666

Shiu, S.-C., \& Lin, S.-Y. (2012). The Relationship Between Learning Motivation and Innovative Behavior in The University Students: From The Perspective of Creative Self-Efficacy, 5(5), 33-38.

Sujarwo, A. (2017). Pengaruh Motivasi Kerja dan Perilaku Inovatif terhadap Kinerja Karyawan dengan Kepuasan Kerja sebagai Variabel Mediasi. Infokam, 13(1), 63-71. 
Tan, A.-G., Li, J., \& Rotgans, J. (2011). Creativity Self-Efficacy Scale as a Predictor for Classroom Behavior in a Chinese Student Context. The Open Education Journal, 4(1), 90-94. https://doi.org/10.2174/1874920801104010090

Tierney, P., \& Farmer, S. M. (2011). Creative Self-Efficacy Development and Creative Performance Over Time. Journal of Applied Psychology, 96(2), 277-293. https://doi.org/10.1037/a0020952

Verhoest, K., Verschuere, B., \& Bouckaert, G. (2007). Pressure, Legitimacy, and Innovative Behavior by Public Organizations. Governance: An International Journal of Policy, Administration, and Institutions, 20(3), 469-497.

Walsh, K. (1995). Public Services and Market Mechanisms: Competition, Contracting and the New Public Management. Basingstoke, UK: Macmillan.

Wynen, J., Boon, J., Kleizen, B., \& Verhoest, K. (2019). How Multiple Organizational Changes Shape Managerial Support for Innovative Work Behavior : Evidence From the Australian Public Service. Review of Public Personnel Administration, 1-25. https://doi.org/10.1177/0734371X18824388

Yu, C., Yu, T. F., \& Yu, C. C. (2013). Knowledge Sharing, Organizational Climate, And Innovative Behavior: A Cross-Level Analysis Of Effects. Social Behavior and Personality, 41(1), 143156.

https://doi.org/http://dx.doi.org/10.2224/sbp.2013.41.1.143

Yuan, F., \& Woodman, R. W. (2010). Innovative Behavior in the Workplace: the Role of Performance and Image Outcome Expectations. Academy of Management Journal, 53(2), 323-341. 